\title{
TREATMENT WITH FERULIC ACID AMELIORATED CISPLATIN-INDUCED NEPHROTOXICITY AND OXIDATIVE STRESS IN TUMOR BEARING MICE
}

\author{
Saratchandran A. Divakaran ${ }^{1,2}$, Anitha $\mathrm{CT}^{3}$
}

\author{
${ }^{1}$ Amala Cancer Research Centre, 680555, Thrissur, Kerala, India \\ ${ }^{2}$ Sree Kerala Varma College, Thrissur, Kerala, 680011, India \\ ${ }^{3}$ Sree Narayana College, Nattika, Thrissur, Kerala, 680566, India \\ Received - May 23, 2021; Revision - July 18, 2021; Accepted - August 02, 2021 \\ Available Online-August 30, 2021
}

DOI: http://dx.doi.org/10.18006/2021.9(4).492.499

KEYWORDS
Ferulic acid
Nephrotoxicity
Oxidative stress
Antioxidant
Tumor
Anticancer

\begin{abstract}
Cisplatin (Cis) is one of the most widely used cytotoxic therapeutic agents for the treatment of cancer. Overdose of the drug resulted in various side effects of genotoxicity and nephrotoxicity. The toxicity of the drug has been attributed to the generation of oxidative free radicals. The current study aims to explore the effect of Ferulic acid (FA) in ameliorating Cis-induced renal toxicity in tumor bearing Swiss albino mice. Nephrotoxicity was induced in tumor bearing mice by a single dose of Cis $(12 \mathrm{mg} / \mathrm{kg}$, i.p). Post administration of FA was carried out $(100 \mathrm{mg} / \mathrm{kg}$ p.o and $200 \mathrm{mg} / \mathrm{kg}$ p.o $)$ one hour after Cis administration. Toxicity was measured by analyzing the amount of serum urea, creatinine, and antioxidant status of renal and tumor tissues. Treatment of cisplatin-administered tumor animals with the FA could prevent the drug-induced oxidative damage as evidenced by the decreased levels of lipid peroxidation and enhanced activities of the antioxidants in the renal tissues. The treatment also protected the renal tissues from the toxic effects of Cis by reducing the levels of serum urea and creatinine. FA protected the renal tissues, whereas it enhanced the anticancer efficacy of Cis in tumor tissues. The histopathological observations support that ferulic acid has a protective effect against Cisplatin-induced nephrotoxicity and can be used to improve the chemotherapeutic index of Cisplatin for cancer treatment.
\end{abstract}

* Corresponding author

E-mail: saratcad@gmail.com anithasajeev913@gmail.com

Peer review under responsibility of Journal of Experimental Biology and Agricultural Sciences.

Production and Hosting by Horizon Publisher India [HPI] (http://www.horizonpublisherindia.in/).

All rights reserved.
All the articles published by Journal of Experimental Biology and Agricultural Sciences are licensed under a Creative Commons Attribution-NonCommercial 4.0 International License Based on a work at www.jebas.org.

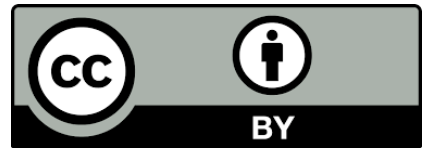




\section{Introduction}

Nephrotoxicity arises as a result of direct exposure to drugs and environmental chemicals to renal tissue (Sales \& Foresto, 2020). Many therapeutic agents such as oxaliplatin, cisplatin, paclitaxel, carboplatin, doclitaxel, vinorelbine, topotecan, etc. are responsible for the induction of nephrotoxicity. These agents are used as chemotherapeutic drugs against different forms of human cancers (Jagieła et al., 2021). To control neoplastic disorders and distant metastases, these agents are administered systemically, which adversely affects normal cells, resulting in cytotoxicity (Janakiraman \& Jayaprakash, 2015).

Cis-Diamminedi chloroplatinum II (Cisplatin or CP or Cis) is one of the foremost effective cancer therapeutic agents, used in the treatment of several solid tumors and refractory non-Hodgkin's lymphomas (Giaccone, 2000). The therapeutic efficacy of cisplatin is usually related to nephrotoxicity (George \& Anushree, 2014). The nephrotoxicity by cisplatin is associated with cellular necrosis, alterations within the number and size of the lysosomes, morphological damage of intracellular organelles, mitochondrial vacuolization, loss of microvilli, and functional changes as inhibition of protein synthesis, lipid peroxidation, mitochondrial damage, and GSH depletion (Awdishu \& Mehta, 2017). Several natural agents like vitamins and/or dietary supplements have the potential to diminish the physiological side effects of those drugs (Ali \& AlMoundhri, 2006; Rad et al., 2017). Such antioxidants protect normal tissues against the deleterious effects of the drug and may be safely manipulated without toxic manifestations (Ojha et al., 2016).

The present study envisages the effect of ferulic acid (FA) on CPinduced nephrotoxicity in tumor bearing Swiss albino mice. Phenolics are widely distributed in the plant kingdom and are an integral part of the human diet as an antioxidant, ferulic acid (FA) or 4-Hydroxy-3-Methoxycinnamic Acid (Figure 1) play a key role within the body's defense against carcinogenesis by inhibiting the formation of N-nitroso compounds (Batista, 2014). Moreover, FA could be a strong scavenger of free radicals and approved in certain countries as an additive to stop lipid peroxidation (Sreenivasan et al., 2007; Panche et al., 2016). FA possesses radioprotective abilities and reduces ionizing radiation-induced damages to DNA and membranes in biological systems (Kumar \& Goel, 2019).

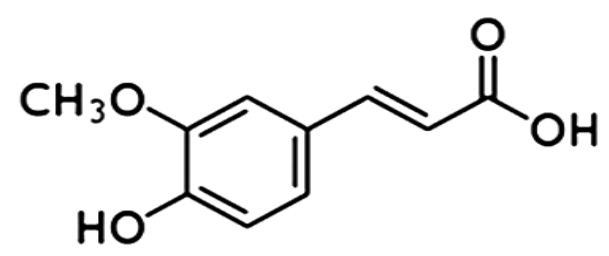

Figure 1 Ferulic acid (FA)

\section{Materials and Methods}

\subsection{Animals}

Female Swiss albino mice (8 - 10 weeks old) weighing 22 - $25 \mathrm{~g}$, obtained from the Small Animal Breeding Section (SABS), Mannuthy, Thrissur, Kerala were used for the study. These experimental animals were kept under standard conditions of temperature and humidity within the Centre's Animal House Facility. The animals got standard mouse chow (Sai Durga Feeds and Foods, Bangalore, India) and water ad-libitum. All animal experiments during this study were carried out with the prior approval of the Institutional Animal Ethics Committee (IAEC) by strictly adhering to the rules of the Committee for the aim of Control and Supervision of Experiments on Animals (CPCSEA) governed by the Animal Welfare Division of Government of India.

\subsection{Chemicals}

Ferulic acid (FA), riboflavin, reduced glutathione (GSH), Nitroblue tetrazolium (NBT), 5-5' dithiobis-2- nitro benzoic acid (DTNB) were bought from Sigma Chemical Company Inc., St. Louis, MO, USA. Hydrogen peroxide $\left(\mathrm{H}_{2} \mathrm{O}_{2}\right)$ was purchased from Merck India Ltd., Mumbai, India. Thiobarbituric acid (TBA) was from Hi-media Laboratories, Mumbai, India. All chemicals and reagents utilized in this study were of AR grade from reputed Indian manufacturers.

\subsection{Drug administration to tumor induced mice}

Cisplatin $(12 \mathrm{mg} / \mathrm{kg}$ i.p) was administered as a single dose to tumor animals.

\subsection{Solid tumor in Animals}

A solid tumor was induced in the hind limbs of mice by transferring Dalton's Lymphoma Ascites (DLA) cells $\left(1 \times 10^{6}\right.$ cells/animal) through subcutaneous injection. The treatments are started when the tumor size reached about $1.0 \mathrm{~cm}^{3}$ on the $13^{\text {th }}$ day of transplantation of DLA cells. The animals were randomly divided into 4 groups of five animals each and treated as Group - I animals were kept as the untreated control group, provided with $0.1 \mathrm{ml}$ saline i.p and $0.1 \mathrm{ml}$ distilled water p.o; Group - II served as Cisplatin control group administered with cisplatin $12 \mathrm{mg} / \mathrm{kg}$ b.w (in $0.1 \mathrm{ml}$ saline i.p as a single dose); Group - III animals were given Cisplatin (12 mg/kg b.w in $0.1 \mathrm{ml}$ saline) i.p as a single dose with Ferulic acid $100 \mathrm{mg} / \mathrm{kg}$ b.w (in $0.1 \mathrm{ml}$ distilled water p.o); and Group - IV animals were provided with Cisplatin (12 $\mathrm{mg} / \mathrm{kg}$ b.w in $0.1 \mathrm{ml}$ saline) i.p as a single dose with Ferulic acid $200 \mathrm{mg} / \mathrm{kg}$ b.w (in $0.1 \mathrm{ml}$ distilled water p.o). FA was administered to groups III and IV, one hour after Cisplatin (12 mg/kg b.w) administration

Journal of Experimental Biology and Agricultural Sciences http://www.jebas.org 


\subsection{Assessment of nephrotoxicity}

Serum creatinine was determined by the alkaline picric acid method (Allen et al., 1982) using a diagnostic kit (Agappe Diagnostic Pvt. Ltd; Ernakulam, Kerala, India). Serum urea was determined by diacetylmonoxime (DAM) reagent using the Agappe diagnostic kit (Kassirer, 1971). In the case of cisplatintreated animals, seventy-two hours after cisplatin treatment (12 $\mathrm{mg} / \mathrm{kg}$ as an intraperitoneal injection) animals were sacrificed using ether anesthesia, blood was collected directly from the heart, serum separated for urea and creatinine analysis. Kidneys and tumors were excised for analyzing the antioxidant status and for histopathological examinations (Divakaran \& Nair, 2012).

Reduced glutathione (GSH) level was measured colorimetrically using DTNB as the substrate. The concentrations of malondialdehyde (MDA) as indices of lipid peroxidation were assessed according to the method of Buege \& Aust (1978). Superoxide dismutase activity was determined by the nitroblue tetrazolium reduction method of Mc Cord \& Fridovich (1969). GPx activity was determined by the method of Hafemann et al. (1974), based on the degradation of $\mathrm{H}_{2} \mathrm{O}_{2}$ in the presence of GSH. Tissue protein was studied according to the method of Lowry et al. (1951) using bovine serum albumin as standard.

\subsection{Histopathological studies}

Histopathological examinations of kidney and tumors from all the treated groups were evaluated using light microscopy. The tissues were fixed in $10 \%$ formalin, embedded in paraffin, sectioned at 5 $\mu \mathrm{m}$, and stained with hematoxylin-eosin. The histopathological studies were done at Sudharma Metrapolis Pathological Laboratory, Thrissur, Kerala, India.

\subsection{Statistical Analysis}

The statistical results are represented as the Mean \pm SD of the studied group. All the analyses were subjected to ANOVA with Tukey- Kramer multiple comparisons test.

\section{Results}

\subsection{Serum Enzyme Levels}

Administration of cisplatin to mice is found to induce a marked renal failure, characterized by a significant increase in serum urea and creatinine levels. As shown in table 1, the levels of serum creatinine and urea concentrations were significantly increased within the cisplatin-treated group when compared with the normal untreated group. Further, the concentrations of serum creatinine and urea in the mice treated by FA ( $200 \mathrm{mg} / \mathrm{kg}$ body weight) shows drastic reduction up to $60 \%$ and $65.27 \%$, respectively, concerning the cisplatin-treated group.
Table 1 Effect of the FA treatment on the serum urea and creatinine levels in mice treated with cisplatin

Treatments Urea $(\mathrm{mg} / \mathrm{dL}) \quad$ Creatinine $(\mathrm{mg} / \mathrm{dL})$

\begin{tabular}{|ccc|}
\hline Normal (Untreated) & $44.33 \pm 4.04$ & $0.53 \pm 0.11$ \\
\hline Cisplatin & $151.66 \pm 7.63$ & $2.5 \pm 0.45$ \\
\hline Cis+FA $100 \mathrm{mg} / \mathrm{Kg}$ & $120.33 \pm 4.50^{\mathrm{a}}$ & $1.76 \pm 0.15^{\mathrm{a}}$ \\
\hline Cis+FA $200 \mathrm{mg} / \mathrm{Kg}$ & $99 \pm 3.60^{\mathrm{a}}$ & $1.5 \pm 0.14^{\mathrm{a}}$ \\
\hline
\end{tabular}

Values given in the table are the mean of five replicates and are expressed as mean $\pm \mathrm{SD}$, 'a' represents $\mathrm{p}<0.001$ vs Cis control

\subsection{Biochemical Measurements and Antioxidant Status}

MDA (Malondialdehyde) was measured as a marker of lipid peroxidation and an indicator of oxidative injury. The MDA levels in nephro tissue were increased significantly within the cisplatintreated group compared with the untreated control group. The increase in MDA by cispaltin was significantly attenuated by the administration of FA (Figure 2). Different antioxidant enzymes were examined in the kidney tissue from all the groups. The Cistreated mice showed a significant decrease in SOD, GPX, and GSH activities compared with the untreated control (Table 2). The decrease in activities of SOD, GPX, and GSH due to cisplatin was suppressed by the treatment of FA.

In tumor tissues, the MDA levels were increased significantly within the Cis treated group compared with the untreated control group. The post administration of FA together with Cis effectively potentiated the formation of MDA in an exceedingly significant manner (Figure 3). The antioxidant enzymes such as GPx, SOD, and GSH activities in the tumor tissues were significantly reduced within the Cis and ferulic acid treated group compared to the respective control (Table 3 ).

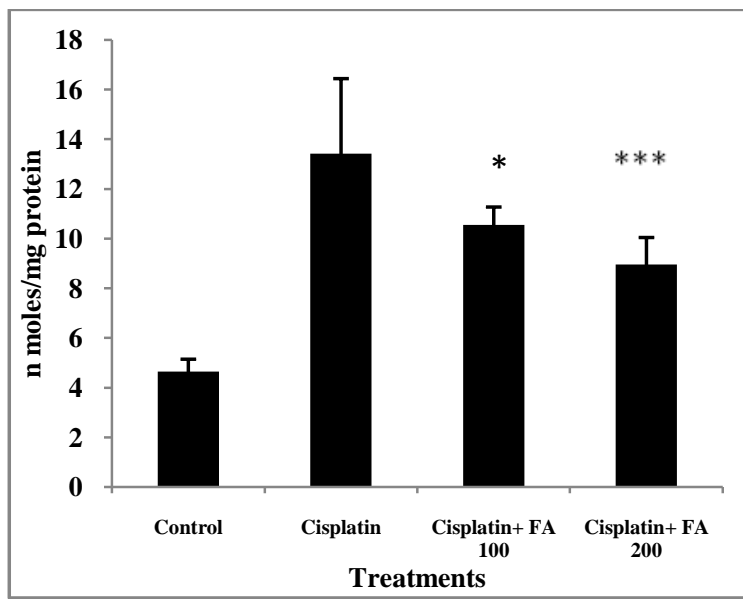

Figure 2 Effect of ferulic acid administration on Cisplatin-induced lipid peroxidation (MDA formation) in kidney tissues of mice.

(* indicate $\mathrm{p}<0.05$ and $* * *$ indicate $\mathrm{p}<0.001$ when compared with the Cis alone treated group) 


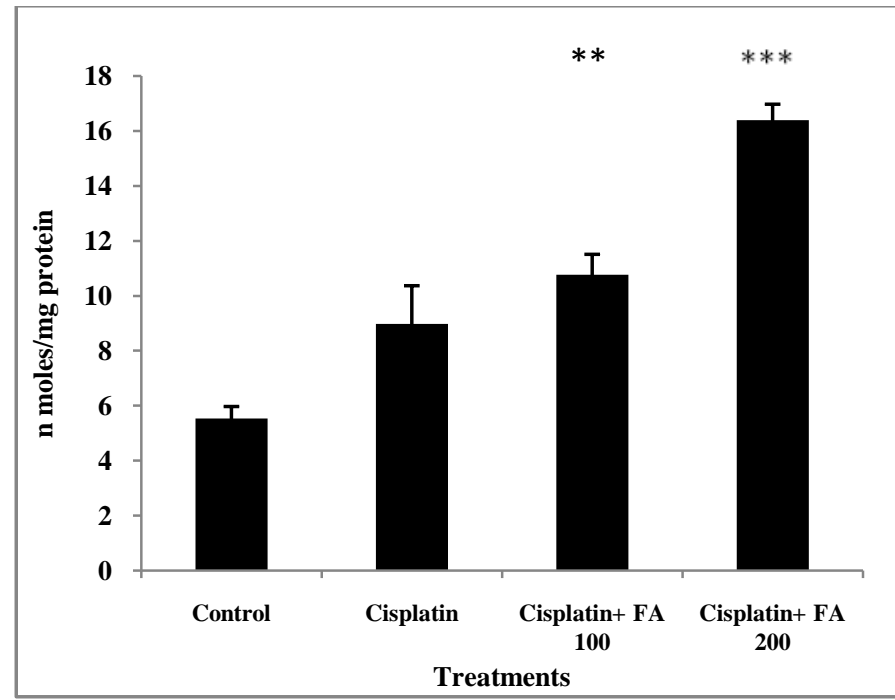

Figure 3 Effect of Ferulic acid administration on cisplatin- induced lipid peroxidation (MDA formation) in tumor tissues of mice. (*** indicate $\mathrm{p}<0.001$ vs Cis control, $* *$ indicate $\mathrm{p}<0.01$ vs Cis control)

Table 2 Effect of p.o. administration of FA on cisplatin-induced damages to renal antioxidant enzymes

\begin{tabular}{|cccc|}
\hline Treatments & GPx (U/mg protein) & GSH (n moles/ mg protein) & SOD (unit/mg protein) \\
\hline Normal (Untreated) & $26.9 \pm 1.34$ & $30.08 \pm 4.77$ & $14.22 \pm 2.07$ \\
\hline Cisplatin & $12.61 \pm 2.14$ & $10.41 \pm 1.67$ & $3.96 \pm 0.19$ \\
\hline Cis+FA $100 \mathrm{mg} / \mathrm{Kg}$ & $13.39 \pm 1.08^{\mathrm{ns}}$ & $13.6 \pm 0.33^{\mathrm{ns}}$ & $5.36 \pm 0.52^{\mathrm{ns}}$ \\
\hline Cis+FA $200 \mathrm{mg} / \mathrm{Kg}$ & $17.75 \pm 1.35^{\mathrm{a}}$ & $16.08 \pm 0.49^{\mathrm{b}}$ & $7.6 \pm 1.54^{\mathrm{a}}$ \\
\hline
\end{tabular}

Values given in the table are the mean of five replicates and are expressed as mean \pm SD, ' $a$ ' represent $\mathrm{p}<0.001$ vs Cis control; 'b' represent $p<0.01$ vs Cis control, 'ns' represent $p>0.05$ vs Cis control

Table 3 Effect of ferulic acid (p.o) administration on the Cisplatin induced depletion of antioxidant levels in tumor tissues of mice

\begin{tabular}{|cccc|}
\hline Treatments & GPx (U/mg protein) & GSH (n moles/ mg protein) & SOD (unit/mg protein) \\
\hline Normal (Untreated) & $28.06 \pm 2.32$ & $27.89 \pm 2.59$ & $10.68 \pm 1.25$ \\
\hline Cisplatin & $18.60 \pm 0.88$ & $16.08 \pm 0.77$ & $6.36 \pm 0.51$ \\
\hline Cis+FA $100 \mathrm{mg} / \mathrm{Kg}$ & $15.26 \pm 2.66^{\mathrm{b}}$ & $12.4 \pm 0.28^{\mathrm{b}}$ & $5.25 \pm 0.57^{\mathrm{c}}$ \\
\hline Cis+FA $200 \mathrm{mg} / \mathrm{Kg}$ & $10.71 \pm 1.70^{\mathrm{a}}$ & $9.06 \pm 1.40^{\mathrm{a}}$ & $4.7 \pm 0.26^{\mathrm{b}}$ \\
\hline
\end{tabular}

Values are expressed as mean $\pm \mathrm{SD}(\mathrm{n}=5)$. 'a' represent $\mathrm{p}<0.001$ vs Cis control ; 'b' represent $\mathrm{p}<0.01$ vs Cis control ; 'c'represent $\mathrm{p}<0.05$ vs Cis control

\subsection{Morphological Study}

Histopathological analysis of cisplatin-treated mice kidney showed a decreased cellularity of the glomeruli, and edema of the epithelial cells lining in the renal tubules as compared to control (Figure 4A), and also the interstitial tissue as evident from figure $4 \mathrm{~B}$. The renal tissues of cisplatin treated mice administered with FA showed normal glomerular, renal tubules, and interstitial tissue appearance. In tumor bearing mice treated with FA and Cis, shows a significant reduction in the severity of renal degeneration was observed (Figure $4 \mathrm{C}$ and D).
The histopathological examination of tumor tissues is detailed in figure 5. Tumor tissues of control animals showed a compact arrangement of carcinomatous cells having clear cytoplasm and hyperchromatic nuclei. Whereas the Cis-treated animals showed many degenerating cells, stroma showed extensive areas of necrosis and hemorrhage. Tumor bearing animals administered with FA and Cis showed a significant increase in the number of degenerating cells. Stroma showed extensive areas of necrosis, cellular integrity was lost in many regions. The results showed that FA potentiates the cytotoxic action of cisplatin in tumor cells (Figure $5 \mathrm{C}$ and D). 

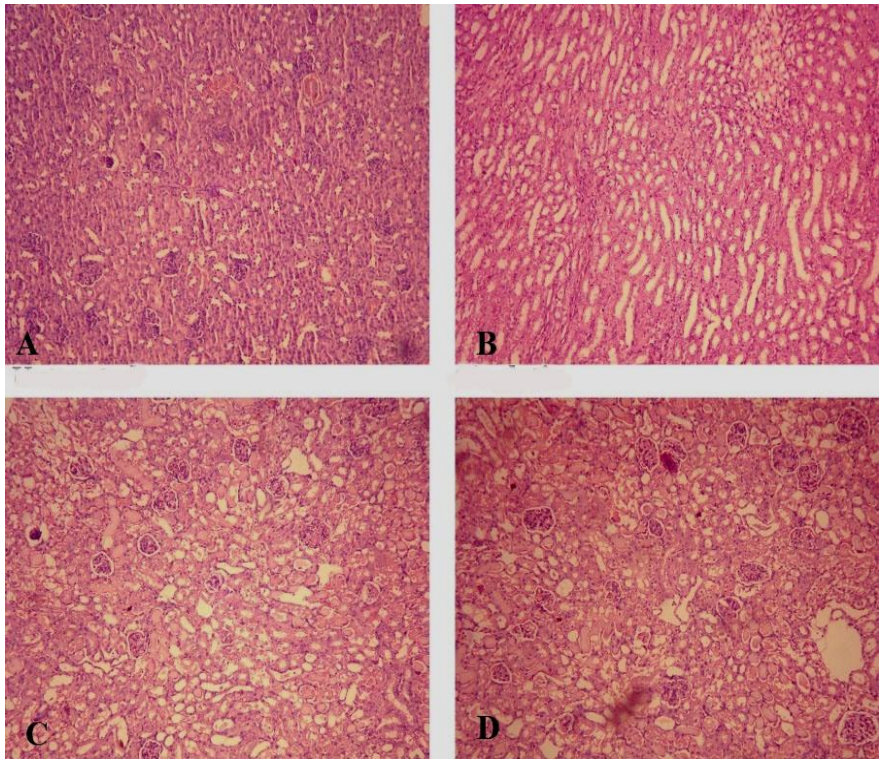

Figure 4 Histopathology study of the representative sections of kidney tissue of tumor bearing mice (A) untreated (B) Cisplatin $12 \mathrm{mg} / \mathrm{kg}$ (C) Cis+FA $100 \mathrm{mg} / \mathrm{kg}$ and (D) Cis+FA $200 \mathrm{mg} / \mathrm{kg}$
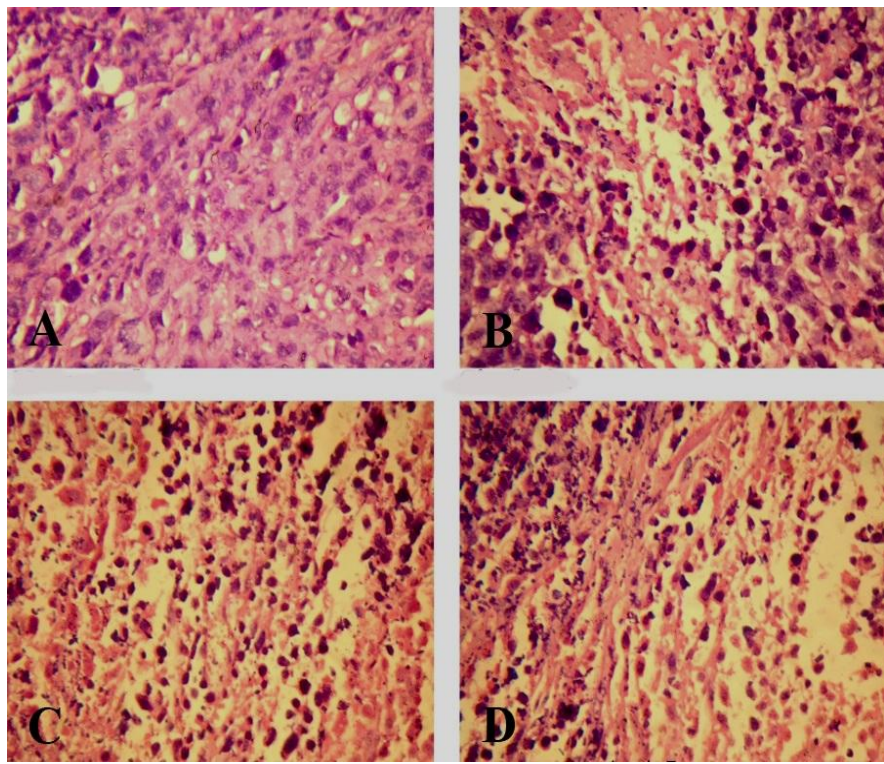

Figure 5 Histopathology study of the representative sections of tumor tissue of tumor bearing mice (A) untreated (B) Cisplatin $12 \mathrm{mg} / \mathrm{kg}$ (C) Cis+FA $100 \mathrm{mg} / \mathrm{kg}$ and (D) Cis+FA $200 \mathrm{mg} / \mathrm{kg}$

\section{Discussion}

Cisplatin is the most widely used anti-cancer agent, best against many solid organ tumors. The major side-effect of cisplatin is nephrotoxicity and its dose is the main limiting factor for its clinical use (Rana et al., 2016). Results of previous studies have shown that a minimum dose of cisplatin $(5 \mathrm{mg} / \mathrm{kg}$ body weight, i.p) was sufficient to induce nephrotoxicity in rats (Boogaard et al., 1991). The highly reactive platinum complexes of Cisplatin binds with nucleophilic DNA via inter and intra-strand crosslinking with guanine nucleotide (Holditch et al., 2019). These events end up in denaturation of DNA and cell cycle arrest. Cisplatin via cytochrome P450 (CYP) in microsome and mitochondrial dysfunctioning creates reactive oxygen species (ROS) and damages the renal tissue (Nematbakhsh et al., 2017).

One of the foremost important mechanisms observed in cisplatin toxicity is oxidative stress (Mohamed \& Shenouda, 2021). Under 
normal physiological conditions, production and removal of reactive oxygen species (ROS) in cells are controlled by the endogenous scavenging system including catalase, superoxide dismutase, and reduced glutathione (Pabla, \& Dong, 2008). Under oxidative stress conditions, ROS levels are elevated, and many cellular structures (proteins, lipids, DNA) can be damaged. Increased oxidative stress can make cellular injury and necrosis in the kidney and other tissues. Previous studies (Kim et al., 2012; Saisruthi \& Sreedevi, 2017) suggested the key role of lipid peroxidation and antioxidant enzymes like SOD and CAT in free radical metabolisms. These antioxidants enzymes scavenge free radicals or convert them into non-toxic end products and are measured as a first-line cellular defense mechanism against oxidative damage. The second line of antioxidant defense consists of the non-enzymatic scavengers such as GSH, which scavenge remaining free radicals escaping from the primary line of antioxidant enzymes defense (Mody et al., 2020).

Administration of cisplatin shows a significant increase in blood creatinine and serum urea concentrations compared to normal, which indicates the intrinsic acute renal failure (Joy \& Nair, 2008; Wu \& Huang, 2018). The results of the current study showed that cisplatin administration to tumor bearing mice significantly raised the levels of lipid peroxidation and caused depletion of GSH, SOD, and GPx in renal tissues. The declined antioxidant status partially explains the mechanism of nephrotoxicity induced by cisplatin. The renal accumulation of platinum, covalent binding of renal protein also play a crucial role in nephrotoxicity (Hanigan \& Devarajan, 2003). The decreased concentration of GSH increases the sensitivity of organs to oxidative and chemical injury. Treatment of FA (100 \& $200 \mathrm{mg} / \mathrm{kg}$ body weight, p.o) together with cisplatin could significantly prevent the depletion of these renal antioxidant systems. Treatment with FA rendered protection because of the increase in GSH concentration could keep the renal cells from oxidants attack. Moreover, the protection of GSH is additionally by forming the substrate for the GPx activity that may react directly with various aldehydes produced from the peroxidation of membrane lipids. Treatment with FA and cisplatin enhances the activity of Se-GPx (selenium-dependent GPx) compared to the cisplatin alone-treated animals. Thus the improved GPx activity partially explained the role in nephro protection. The decreased activity of SOD and GPx in renal tissues enhanced the lipid peroxidation in cisplatin treated group (Jia et al., 2011; Moreno-Gordaliza et al., 2018). Treatment with FA prevented lipid peroxidation by enhancing the renal SOD and GPx activities.

The main prerequisite for any compound to be used as a nephroprotective agent during the treatment of cancer is that it should not interfere with the antitumor activity of the chemotherapy (Fang et al., 2021). Various studies in animals and humans confirmed that FA could demonstrate anticancer properties
(Divakaran \& Nair, 2012). Ferulic acid is effective in protecting against oxidative damage in tissues, and also suppresses the formation of carcinogens like nitrosamines. The MDA levels of tumor tissues in FA and Cis-treated animals showed an increase in the level when compared to the untreated control animals. The antioxidant levels in tumor tissues were also found to be significantly reduced by the administration of cisplatin and ferulic acid. The results significantly showed the antitumor potential of the combination treatment (Humanes et al., 2012). Moreover, the histopathological reports suggest that post-treatment of FA greatly inhibited the Cis-induced changes in kidney tissue supporting the protective action of FA against Cis-induced nephrotoxicity and offer maximum destruction to tumor tissues (Zhao \& Dai, 2020).

\section{Conclusion}

The results of this study can be concluded that ferulic acid (100 $\& 200 \mathrm{mg} / \mathrm{kg}$ body weight) rendered significant protection against cisplatin-induced oxidative renal damage. FA offers renal protection by preventing the cisplatin-induced decline of renal antioxidant status. The protective effect may result to direct scavenging of the electrophilic free radicals by antioxidant FA. Thus, the present study indicates the potential antitumor use of FA in preventing cisplatin-induced renal toxicity in clinical practice. The combination treatment of ferulic acid and cisplatin in tumor bearing mice restored all the biochemical parameters altered by the cytotoxic drug nearer to normal levels in renal tissues. FA protected the kidney tissues from Cis-induced renal toxicity by enhancing the endogenous antioxidant levels, lowering the serum urea and creatinine levels. Thus prevents the damages of renal tissues. The combined strategy showed high antitumor activity as evident from MDA formation, antioxidant enzyme levels, and histopathological examination. The strategy ensures a secure and efficient anticancer treatment modality. Thus, the combination treatment improves the chemotherapeutic index of cytotoxic anticancer drug, Cisplatin.

\section{Acknowledgments}

The authors express their gratitude to Amala Cancer Research Centre, Thrissur, Kerala, India, and Sree Narayana College, Nattika, Thrissur, Kerala, India for the support given to Anitha CT and Saratchandran A Divakaran.

\section{Conflict of interest}

The authors report no conflicts of interest. The authors only are answerable for the content and inscription of the paper

\section{References}

Ali BH, AlMoundhri MS (2006) Agents ameliorating or augmenting the nephrotoxicity of cisplatin and other platinum 
compounds: a review of some recent research. Food and Chemical Toxicology 44: 1173-1183.

Allen LC, Michalko K, Coons C (1982) More on cephalosporin interference with creatinine determinations. Clinical chemistry 28 (3): $555-556$.

Awdishu L, Mehta RL (2017) The 6R's of drug induced nephrotoxicity. BMC Nephrology 18:124.

Batista R (2014) Uses and potential applications of ferulic acid. In: Warren B (ed). Ferulic acid: antioxidant properties, uses and potential health benefits, 1 Ed. Nova Science Publishers, Inc., New York, USA 39-70.

Boogaard PJ, Lempers EL, Mulder GJ, Meerman JHN (1991) 4 methylthiobenzoic acid reduces cisplatin nephrotoxicity in rats without compromising anti-tumor activity. Biochemical Pharmacology 41: 1997-2003.

Buege AJ, Aust SD (1978) Microsomal Lipid Peroxidation Methods in Enzymology 52: 302-310.

Divakaran SA, Nair CKK (2012) Amelioration of Doxorubicin Induced Cardiotoxicity in Tumor Bearing Mice by Ferulic Acid: a Mechanistic Study at Cellular and Biochemical Level International Journal of Tumor Therapy 1(2): 6-13.

Fang C, Lou D, Zhou L., et al. (2021) Natural products: potential treatments for cisplatin-induced nephrotoxicity. Acta Pharmacologica Sinica. https://doi.org/10.1038/s41401-021-00620-9.

George SP, Anushree CS (2014) Drug-induced impairment of renal function. International Journal of Nephrology and Renovascular Disease 7: 457-68.

Giaccone G (2000) Clinical perspectives on platinum resistance. Drugs 59:9-17.

Hafemann DG, Sunde RA, Hoekstra WG (1974) Effect of dietary selenium on erythrocyte and live glutathione peroxides in the rat. Journal of Nutrition 104: 580-87.

Hanigan MH, Devarajan P (2003) Cisplatin nephrotoxicity: molecular mechanisms. Cancer Therapy 1-47.

Holditch SJ, Brown CN, Lombardi AM, Nguyen KN, Edelstein CL (2019) Recent Advances in Models, Mechanisms, Biomarkers, and Interventions in Cisplatin-Induced Acute Kidney Injury. International Journal of Molecular Sciences 20: 3011.

Humanes B, Lazaro A, Camano S, Gordaliza EM, Lazaro JA, Codesido MB, Lara JM, Ortiz A, Gomez MG, Vasallo PM, Tejedor A (2012) Cilastatin protects against cisplatin-induced nephrotoxicity without compromising its anticancer efficiency in rats. Kidney International 82: 652-663; doi:10.1038/ki.2012.199

Jagieła J, Bartnicki P, Rysz J (2021) Nephrotoxicity as a Complication of Chemotherapy and Immunotherapy in the Treatment of Colorectal Cancer, Melanoma and Non-Small Cell Lung Cancer. International Journal of Molecular Sciences 22: 4618. https:// doi.org/10.3390/ijms22094618

Janakiraman M, Jayaprakash K (2015) Nephroprotective potential of medicinal plants: A Review. International Journal of Science and Research 4(9): 543-547.

Jia Z, Wang N, Aoyagi T, Wang H, Liu H, Yang T (2011) Amelioration of cisplatin nephrotoxicity by genetic or pharmacologic blockade of prostaglandin synthesis. Kidney International 79:77-88; doi:10.1038/ki.2010.331

Joy J, Nair CKK (2008) Amelioration of cisplatin induced nephrotoxicity in Swiss albino mice by Rubia cordifolia extract. Journal of Cancer Research and Therapeutics 4(3): 111-115.

Kassirer JP (1971) Clinical evaluation of kidney functionglomerular function. The New England Journal of Medicine 285 (7):385-389.

Kim J, Long KE, Tang K, Padanilam BJ (2012) Poly(ADP-ribose) polymerase 1 activation is required for cisplatin nephrotoxicity. Kidney International 82: 193-203; doi:10.1038/ki.2012.64

Kumar N, Goel N (2019) Phenolic acids: Natural versatile molecules with promisingtherapeutic applications. Biotechnology Reports 24: e00370.

Lowry OH, Rosenblum NJ, Farr AL, Randall J (1951) Protein measurement with folin fenol reagent. Journal of Biological Chemistry193:265-75.

McCord JM, Fridovich I (1969) Superoxide dismutase enzyme function for erythrocuprein (hemocuprein). Journal of Biological Chemistry 244: 6049-6056.

Mody H, Ramakrishnan V, Chaar M, Lezeau J, Rump A, Taha K, Lesko L, Ait- Oudhia S (2020) A Review on Drug-Induced Nephrotoxicity: Pathophysiological Mechanisms, Drug Classes, Clinical Management, and Recent Advances in Mathematical Modeling and Simulation Approaches. Clinical Pharmacology in Drug Development 9(8): 896-909.

Mohamed HZ, Shenouda MB (2021) Amelioration of renal cortex histological alterations by aqueous garlic extract in gentamicin induced renal toxicity in albino rats: a histological and immunohistochemical study. Alexandria Journal of Medicine 57 (1): 28-37. 
Moreno-Gordaliza EM, Esteban-Fernández D, Alberto Lázaro A, Aboulmagd S, Humanes B, Tejedor A, Linscheid MW, GómezGómez MM (2018) Lipid imaging for visualizing cilastatin amelioration of cisplatin-induced nephrotoxicity. Journal of Lipid Research 59: 1561-1574.

Nematbakhsh M, Pezeshki Z, Jazi FE, Mazaheri B, Moeini M, Safari T, Azarkish F, Moslemi F, Maleki M, Rezaei A, Saberi S, Dehghani A, Malek M, Mansouri A, Ghasemi M, Zeinali F, Zamani Z, Navidi M, Jilanchi S, Shirdavani S, Ashrafi F (2017) Cisplatin-Induced Nephrotoxicity; Protective Supplements and Gender Differences. Asian Pacific Journal of Cancer Prevention 18 (2): 295-314.

Ojha S, Venkataraman, B, Kurdi A, Mahgoub E Sadek B, Rajesh M (2016) Plant-Derived Agents for Counteracting CisplatinInduced Nephrotoxicity. Oxidative Medicine and Cellular Longevity Article ID 4320374. doi: 10.1155/2016/4320374.

Pabla N, Dong Z (2008) Cisplatin nephrotoxicity: Mechanisms and renoprotective strategies. Kidney International 73: 994-1007. doi:10.1038/sj.ki.5002786

Panche AN, Diwan AD, Chandra SR (2016) Flavonoids: an overview. Journal of Nutritional Science 5:e47. doi: 10.1017/jns.2016.41.

Rad AK, Mohebbati R, Hosseinian S (2017) Drug-induced
Nephrotoxicity and Medicinal Plants. Iranian journal of Kidney Disease 11:169-79.

Rana MA, Khan RA, Nasiruddin M, Khan AA (2016) Amelioration of Cisplatin-Induced Nephrotoxicity by Ethanolic Extract of Bauhinia purpurea: An in vivo Study in Rats. Saudi Journal of Kidney Disease and Transplantation 27(1):41-48.

Saisruthi K, Sreedevi A (2017) Amelioration of Cisplatin- Induced Nephrotoxicityby Roots of Anthocephalus cadamba. Biomedical \& Pharmacology Journal 10(3): 1433-1439.

Sales GT, Foresto RD (2020) Drug-induced nephrotoxicity. Revista da Associacao Medica Brasileira 66(1): 82-90.

Sreenivasan M, Sudheer AR, Menon VP (2007) Ferulic acid : Therapeutic Potential Through its antioxidant property. Recent Advances In Indian Herbal Drug Research. Journal of Clinical Biochemistry and Nutrition 40: 92-100.

Wu H, Huang J (2018) Drug induced nephrotoxicity: Pathogenic mechanisms, Biomarkers and Prevention strategies. Current Drug Metabolism 19 (7): 559-567.

Zhao Y, Dai W (2020) Effect of Phloretin Treatment Ameliorated the Cisplatin-Induced Nephrotoxicity and Oxidative Stress in Experimental Rats. Pharmacognosy Magazine 16(69): 207-2013. 